\title{
Surgical therapy of primary hepatic angiosarcoma
}

\author{
Verena Tripke ${ }^{1} \mathbb{D}$, Stefan Heinrich', Tobias Huber ${ }^{1}$, Jens Mittler ${ }^{1}$, Maria Hoppe-Lotichius ${ }^{1}$, Beate K. Straub ${ }^{2}$ and \\ Hauke Lang ${ }^{1 *}$
}

\begin{abstract}
Background: Primary hepatic angiosarcoma (PHA) is a rare tumor entity. Radical surgical resection is currently considered the best treatment choice. The aim of this analysis is to report our experience with surgery for PHA.

Methods: All resections of PHA from 01/2002 until 06/2017 were identified from our prospective institutional database. All cases were re-confirmed by a second pathologist. We analyzed completeness of resection, overall (OS) and disease-free survival (DFS).

Results: Nine patients with PHA underwent hepatic resection. Median follow-up after surgery was 15.5 months (range: 3-144). At last follow-up 4/9 patients were alive, three of them without recurrence 15, 21 and 144 months after surgery. Five patients developed PHA recurrence. Four of these died 3 to 17 months after surgery. One patient with PHA recurrence is alive 15 months after surgery. Another patient without PHA recurrence died 59 months after surgery from pancreatic cancer. Median OS and DFS after resection was 18 months (range: 3-144 months) and 10 months (range: 2-144 months), respectively. After R-0 resection $(n=8)$, the median OS and DFS was 59 and 11 months.
\end{abstract}

Conclusions: Resection of PHA is the only approach to achieve complete tumor removal and offers a chance for long-term survival and should be evaluated in cases of PHA.

Keywords: Liver resection, Surgical oncology, Liver malignancies

\section{Background}

Primary hepatic angiosarcoma (PHA) is rare malignant tumor of endothelial origin, representing only $1-2 \%$ of all primary liver malignancies [1]. Accepted risk factors are the exposure to vinyl chloride monomers [2], arsenic salts [3] and thorotrast [4] as well as the use of androgenic steroids [5]. Patients usually present with unspecific symptoms such as abdominal pain, fever and weight loss. In almost $25 \%$ of cases the tumor is diagnosed after rupture and abdominal hemorrhage [6]. The majority of patients presents with large, often multifocal or even metastatic disease at the time of diagnosis [7].

Due to the rarity of the tumor there is hardly any data regarding best treatment and prognostic factors. Current treatment approaches are based on case reports and very small case series, only. Radical surgical resection seems

\footnotetext{
* Correspondence: hauke.lang@unimedizin-mainz.de

${ }^{1}$ Department of General, Visceral and Transplantation Surgery, University

Hospital of Mainz, Langenbeckstrasse 1, 55131 Mainz, Germany

Full list of author information is available at the end of the article
}

to be the only curative treatment option for PHA [6]. Chemotherapy or transcatheter arterial chemoembolization (TACE) are used with palliative intention only in a palliative setting while transcatheter arterial embolization (TAE) has been reported to be effective in controlling acute bleeding $[8,9]$. A multicenter retrospective study from Miller et al. suggests beneficial effects of transarterial radioembolization (TARE) for the palliative treatment of soft tissue sarcomas of the liver [10].

The aim of this study was to analyze our experience with hepatic resection for PHA and to compile data about surgical treatment in this rare malignancy.

\section{Methods}

All patients who underwent surgery for PHA from 01/2002 until 06/2017 were identified from our prospective institutional liver surgery database. Data were analyzed with regard to patients' characteristics, clinical and perioperative parameters, completeness of resection as well as overall (OS) and disease-free survival (DFS). All cases were 
histologically examined and confirmed by a second pathologist. A preoperative biopsy positive for PHA was only available in three cases. Postoperative surgical complications were graded according to the Dindo-Clavien classification [11]. Follow-up ended on March 31, 2018.

\section{Statistics}

Overall (OS) and disease-free survivals (DFS) were calculated from the date of surgery until death or tumor recurrence using the Kaplan-Meier method. Continuous variables were presented as median/range or mean/SD, whereas categorical variables were presented as numbers and percentages. SPSS Version 23 (IBM Corporation, USA) was used for statistical analysis.

\section{Results}

Out of 2520 liver resections during the period of analysis, a total of $9(0.4 \%)$ resections for PHA were identified. Patient's characteristics are presented in Table 1.

In 5/9 patients, tumors were symptomatic (abdominal pain) while in 4 cases PHA was diagnosed incidentally upon CT/MRI $(n=2)$ or during surgery for other indications $(n=2)$.

Three patients suffered from liver cirrhosis (Child A). There were 5 solitary and 4 multifocal intrahepatic PHA. No patient had extrahepatic metastatic disease. Preoperative biopsy was available in three cases. All these cases were positive for PHA, two were graded G1, while one case was graded G2. In one patient with multifocal PHA 6 cycles of neoadjuvant chemotherapy with paclitaxel were administered prior to resection. Operative procedures included major hepatectomy $(n=3)$, bisegmentectomy $(n=2)$ and segmentectomies or non-anatomical resections $(n=4)$. A complete resection (R0) was achieved in $8 / 9$ of the cases. One resection of a multifocal PHA, that was intended to be a complete resection, was classified as R1 in the final histological report.

One patient with multifocal PHA received 5 cycles adjuvant therapy with doxorubicin and ifosfamid after surgery.

\section{Morbidity and mortality}

Postoperative complications occurred in 6/9 patients. There were two grade I, one grade II, one grade IIIa (bile leakage requiring percutaneous drainage) and two grade IIIb (postoperative hemorrhages) complications, but no grade IV or V complication. Both 30- and 90-day postoperative mortality were $0 \%$.

\section{Follow-up}

The median follow-up was 15.5 months (range: 3-144 months).

At last follow-up 4 out of 9 patients were alive with 3 of them without recurrence 15, 21 and 144 months after surgery, respectively. In these patients, tumor grading of PHA was G1 each. One patient without tumor-recurrence died 59 months after surgery for PHA due to pancreatic cancer. He had received neoadjuvant chemotherapy with paclitaxel prior to resection. The histological grading was G2.

\section{Treatment of recurrence}

Five patients developed tumor recurrence within 8 months after surgery (median 3.5 months). The histological grading of PHA had been G2 or G3.

Table 1 Patients' characteristics and operative data

\begin{tabular}{|c|c|c|c|c|c|c|c|c|c|c|c|}
\hline Pat. & Age (yrs.) & Gender & Symptoms & ASA & Type of Surgery & Multi-focal & $\begin{array}{l}\text { Tumor size } \\
(\mathrm{cm})\end{array}$ & $\begin{array}{l}\text { Radicality } \\
\text { (R0/R1)/ } \\
\text { Grading }\end{array}$ & Complications & $\begin{array}{l}\text { DFS } \\
\text { (months) }\end{array}$ & $\begin{array}{l}\text { OS } \\
\text { (months) }\end{array}$ \\
\hline 1 & 62 & Male & $\begin{array}{l}\text { Abdominal } \\
\text { pain }\end{array}$ & 3 & Segmentectomy & $\mathrm{No}$ & 1.5 & R0; G1 & $\begin{array}{l}\text { Postoperative } \\
\text { hemorrhage (IIlb) }\end{array}$ & 144 & 144 (alive) \\
\hline 2 & 48 & Male & $\begin{array}{l}\text { Abdominal } \\
\text { pain }\end{array}$ & 3 & Bisegmentectomy & Yes & 7.5 & R0; G2 & $\begin{array}{l}\text { Postoperative } \\
\text { hemorrhage (IIIb) }\end{array}$ & 3.5 & 17 (deceased) \\
\hline 3 & 61 & Female & $\begin{array}{l}\text { Abdominal } \\
\text { pain }\end{array}$ & 2 & $\begin{array}{l}\text { Right } \\
\text { hemihepatectomy }\end{array}$ & Yes & 18 & R0; G3 & $\begin{array}{l}\text { Gastrointestinal } \\
\text { bleeding (II) }\end{array}$ & 2.5 & 3 (deceased) \\
\hline 4 & 49 & Male & $\begin{array}{l}\text { Incidental finding } \\
\text { on imaging }\end{array}$ & 2 & $\begin{array}{l}\text { Left } \\
\text { hemihepatectomy }\end{array}$ & Yes & 4 & R0; G2 & $\begin{array}{l}\text { Wound } \\
\text { infection (I) }\end{array}$ & 59 & 59 (deceased) \\
\hline 5 & 66 & Male & $\begin{array}{l}\text { Incidental finding } \\
\text { on imaging }\end{array}$ & 3 & $\begin{array}{l}\text { non-anatomical } \\
\text { resection }\end{array}$ & No & 1.5 & R0; G2 & $\begin{array}{l}\text { Hepatic } \\
\text { dysfunction (I) }\end{array}$ & 8 & 11 (deceased) \\
\hline 6 & 74 & Female & Abdominal pain & 3 & Bisegmentectomy & No & 4 & $\mathrm{R} 1 ; \mathrm{G} 2$ & None & 2.5 & 3 (deceased) \\
\hline 7 & 75 & Male & $\begin{array}{l}\text { Incidental finding } \\
\text { during surgery }\end{array}$ & 3 & $\begin{array}{l}\text { non-anatomical } \\
\text { resection }\end{array}$ & No & 1.3 & $\mathrm{R} 0 ; \mathrm{G} 1$ & None & 21 & 21 (alive) \\
\hline 8 & 62 & Female & $\begin{array}{l}\text { Incidental finding } \\
\text { during surgery }\end{array}$ & 2 & $\begin{array}{l}\text { non-anatomical } \\
\text { resection }\end{array}$ & No & 1.8 & R0; G1 & None & 15 & 15 (alive) \\
\hline 9 & 55 & Female & Abdominal pain & 3 & $\begin{array}{l}\text { Right } \\
\text { hemihepatectomy }\end{array}$ & Yes & 17 & $\mathrm{RO} ; \mathrm{G} 2-3$ & Bile leakage (IIIa) & 7 & 14.5 (alive) \\
\hline
\end{tabular}


Initial site of tumor recurrence was diffuse intrahepatic in all cases. Two of these five patients had initially multifocal disease and developed early recurrence within three months. Due to a poor general condition, these patients were unable to receive palliative chemotherapy. They died only two weeks after diagnosis of tumor recurrence. Two other patients received palliative chemotherapy with paclitaxel for tumor recurrence: one patient died 3 months after diagnosis of intrahepatic tumor recurrence (11 months after surgery), while the other patient was still alive at last follow-up for 14.5 months after surgery (and 7 months after diagnosis of recurrence). One patient, who developed intrahepatic tumor recurrence 3.5 months after surgery, was initially treated with TACE. During the course of disease, bone metastasis was diagnosed and a palliative chemotherapy with ifosfamid/doxorubicin was initiated. The patient survived for 17 months after surgery.

\section{Survival}

Median OS and DFS after resection was 18 months (range: 3-144 months) and 10 months (range: 2-144 months), respectively. After R0-resection $(n=8)$, the median OS and DFS was 59 and 11 months (Fig. 1).

\section{Discussion}

Due to the low incidence of PHA the current literature is based on case reports and few very small case series, only. In the absence of established treatment guidelines radical surgical resection (R0 status) is currently considered the best treatment to give patients with PHA a decent chance for long-term survival [12-14].

Out of 2520 liver resections on a 15-year period, we identified 9 patients with histologically confirmed PHA. This is to our knowledge the largest case series of

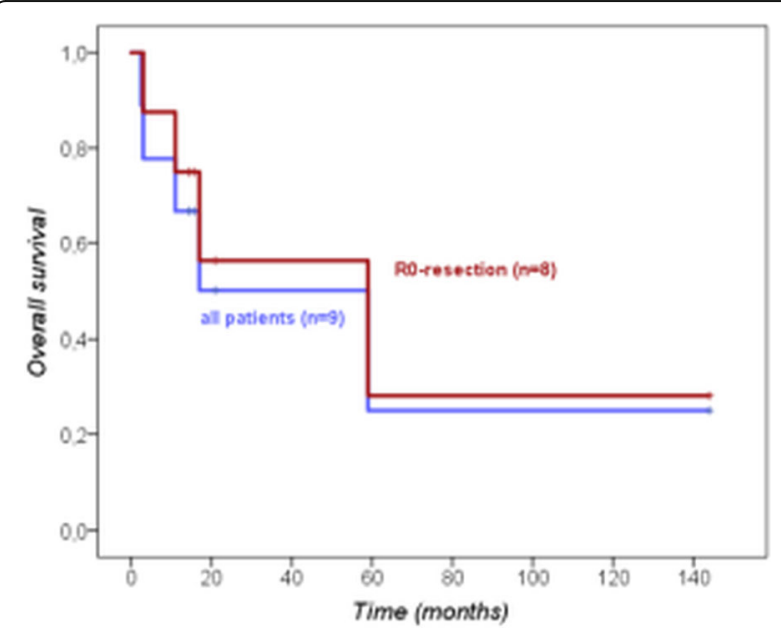

Fig. 1 Overall survival of patients with PHA after surgery $(n=9)$ and after R0-resection $(n=8)$ surgically treated patients with PHA from a single-center in the western world (Table 2).

In our series the median postoperative survival was 18 months in all patients and 59 months in case of R0-resection. A meta-analysis of 64 cases from Zheng et al. reports a median survival of 5 months for the entire collective of patients with PHA, whereas patients $(n=30$ in total) having complete tumor resection alone or in combination with adjuvant chemotherapy had a median OS of 17 months [6]. Patients with a PHA confined to the liver had a longer median survival than those with metastatic tumors (9 months versus 3 months). Consistently, it is not surprising that patients with a small solitary PHA tend to have a better prognosis than those with large or multifocal tumors (Fig. 2). In our series, there were even 4 cases (out of 8 with R0-resection) where the PHA had been diagnosed incidentally. The detection and treatment in a very early stage of disease is the most obvious reason for the overall survival of even 59 months after R0-resection in our series which is remarkably better than all data reported before.

In our series patients with multifocal PHA had a high rate of very early intrahepatic recurrence, all finally resulting in liver failure within a few months. In some patients, general status deteriorated rapidly preventing even any palliative treatment. Nevertheless, surgical resection seems to be at least an option not only to remove tumor burden but also to offer the chance for long-term survival, as shown in one of our patients who survived more than 10 years without recurrence. Similarly, Matthaei et al. reported on one long-term tumor-free survival of more than 8 years in 1 of 5 patients after complete resection [15]. In view of the low perioperative morbidity, these data justify surgical resection as a radical approach for PHA, the more, as PHA is considered an absolute contraindication for liver transplantation, currently. There is only one 5 year-survivor after liver transplantation (LT) in the literature. In general, the outcome of LT for PHA is very poor [16-19]. In a report of 22 cases of LT for PHA, the median survival was 6 months. Five of the 22 patients died due to infections and 17 due to tumor recurrence [17].

Therefore, the herein presented data as well as the few data from literature suggest that the option of surgical resection should be evaluated in all patients with PHA confined to the liver. Depending on the tumor burden and considering patients' general condition as well as the patients' will, even extended surgery can be performed with very low mortality.

Histological grading seems also to be important to predict patients` prognosis [20]. In our series, patients with tumor recurrence had mainly G2 or G3 tumors, whereas patients without tumor recurrence had welldifferentiated (G1) or G2 tumors (Fig. 3). The value of 
Table 2 Case series of PHA

\begin{tabular}{|c|c|c|c|c|c|}
\hline Author (year) & Country & Number & Operation & Other Treatment & Median survival \\
\hline $\begin{array}{l}\text { Molina et al. } \\
\text { [1] (2003) }\end{array}$ & America & 5 & $\begin{array}{l}2 \text { operation + chemotherapy, } \\
1 \text { operation }\end{array}$ & 2 conservative & 2 months \\
\hline $\begin{array}{l}\text { Weitz et al. } \\
\text { [23] (2007) }\end{array}$ & America & 5 & 3 operation (2 potentially curative) & 2 no operation & n.a. ${ }^{a}$ \\
\hline $\begin{array}{l}\text { Kim et al. } \\
\text { [13] (2009) }\end{array}$ & Korea & 5 & - & 4 chemotherapy, 1 conservative & 3 months \\
\hline $\begin{array}{l}\text { Matthaei et al. } \\
\text { [5] (2009) }\end{array}$ & Germany & 5 & 5 operation & - & 30 months \\
\hline $\begin{array}{l}\text { Park et al. } \\
\text { [9] (2009) }\end{array}$ & Korea & 6 & - & 4 TACE, 2 TAE & 3.5 months \\
\hline $\begin{array}{l}\text { Zhou et al. } \\
\text { [12] (2010) }\end{array}$ & China & 6 & 1 operation, 5 operation + TACE & - & 12 months \\
\hline $\begin{array}{l}\text { Huang et al. } \\
\text { [24] (2011) }\end{array}$ & China & 9 & 3 operation + chemotherapy, 1TAE + operation & 4 conservative, 1 TAE + TACE & 4 months \\
\hline $\begin{array}{l}\text { Chi et al. } \\
\text { [25] (2011) }\end{array}$ & China & 7 & 3 operation, 2 liver transplantation & 2 conservative & 6.5 months \\
\hline $\begin{array}{l}\text { Duan et al. } \\
\text { [7] (2012) }\end{array}$ & China & 6 & $\begin{array}{l}5 \text { operation, } 1 \text { operation + chemotherapy } \\
1 \text { operation + chemotherapy, }\end{array}$ & - & 40.5 months \\
\hline $\begin{array}{l}\text { Bruegel et al. } \\
\text { [21] (2012) }\end{array}$ & Germany & 7 & 1 operation & 4 chemotherapy & 16 months \\
\hline $\begin{array}{l}\text { Hur et al. } \\
\text { [26] (2015) }\end{array}$ & Korea & 8 & 1 operation & 1 TACE, 4 chemotherapy, 2 conservative & 214 days \\
\hline $\begin{array}{l}\text { Huang et al. } \\
\text { [14] (2016) }\end{array}$ & Taiwan & 6 & 1 operation & $\begin{array}{l}1 \text { chemotherapy, } 1 \text { chemotherapy + cyberknife, } \\
1 \text { cyberknife, } 2 \text { conservative }\end{array}$ & n.a. \\
\hline $\begin{array}{l}\text { Zhu et al. } \\
\text { [27] (2015) }\end{array}$ & China & 2 & 2 operation & - & 12 months \\
\hline $\begin{array}{l}\text { Present study } \\
\text { (2018) }\end{array}$ & Germany & 9 & 9 operation & - & 18 months \\
\hline
\end{tabular}

n.a. not available; ${ }^{a}$ both patients with potentially curative resection died within 11 months after surgery

preoperative biopsy is controversial as a representative probe cannot be guaranteed, if samples were taken from necrotic areas or surrounding liver parenchyma. Besides, percutaneous biopsy carries a considerable risk for intraabdominal bleeding and may induce metastatic spread.
In our series preoperative biopsy positive for PHA was available in three cases. Biopsy was graded G1 in one case. However, final histology after resection revealed a G3 tumor, so the biopsy had not been representative for the whole tumor. Therefore the value of preoperative biopsy as a prognostic tool is debatable.

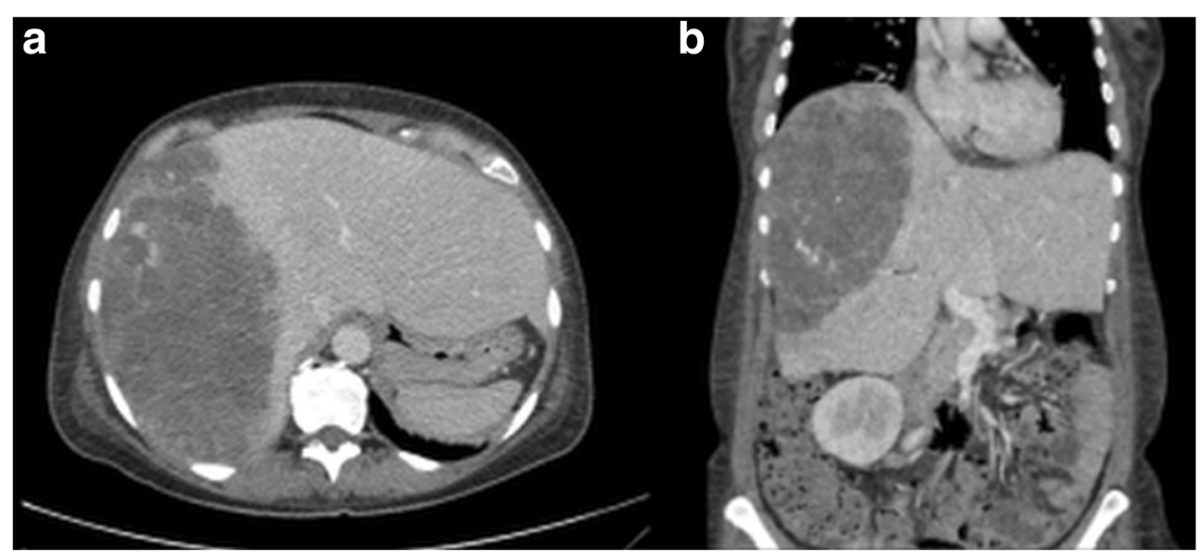

Fig. 2 Preoperative contrast enhanced computed tomography scan showed a heterogenous mass in the right liver lobe (a and $\mathbf{b}$ ) 


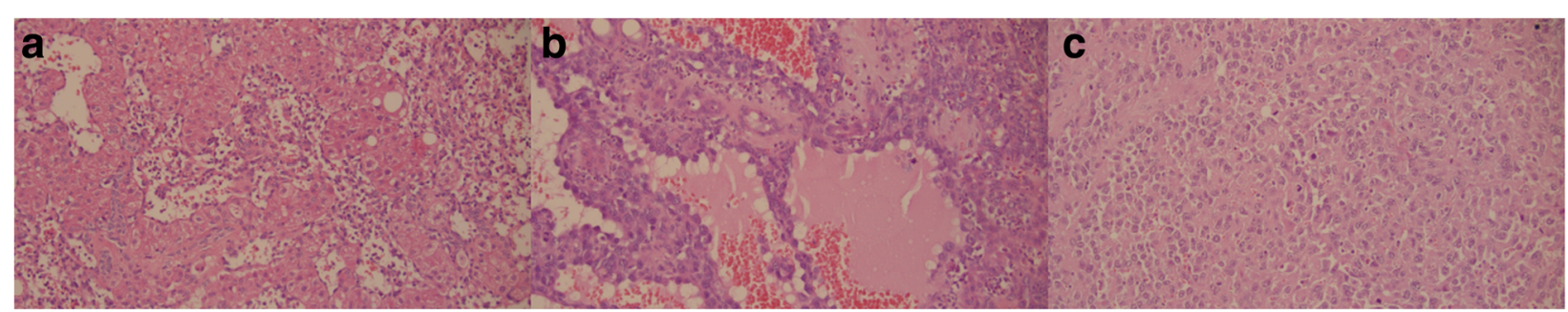

Fig. 3 Pathology findings (hematoxylin and eosin staining, $\times 200$ ) showing sinusoidal and spindle-shape growth of the malignant endothelial cells: G1 (a), G2 (b) and G3 (c)

Of note, patients with tumor rupture have a dismal prognosis of often less than one month $[6,9]$.

Preoperative imaging via computed tomographic scan or magnetic resonance is also a challenge as differentiation from other liver tumors like hemangioma, intrahepatic cholangiocarcinoma or metastases is difficult as PHA shares similar imaging characteristics [21].

Currently, there is no evidence for the efficacy of chemotherapy. Some very small case series suggest a survival benefit for patients who receive palliative chemotherapy with adriamycin/cisplatin/ifosamid/paclitaxel (two patients surviving for more than 14 months after diagnosis; [8]) or doxorubicin/carboplatin and 5-fluorouracil (2 patients surviving 9 and 16 months, respectively; [13]).

The Angiotax study of weekly paclitaxel for angiosarcoma reported median OS of 8 months [22]. Chemotherapy is considered a treatment option in cases of unresectable or metastatic disease. Currently, the value of neoadjuvant chemotherapy remains unclear.

In few papers, the use of transarterial embolization (TAE) or transarterial-chemoembolization (TACE) has been addressed. While TAE is effective in the management of acute bleeding due to rupture, TACE is mainly used in palliative oncological intention. The survival after TACE in few cases ranges up to one year [9].

\section{Conclusion}

In conclusion, oncological treatment data on PHA is very limited at the moment as only few case reports and very small series exist in the literature. In the absence of effective chemotherapy or other tumor directed treatment modalities, and despite high recurrence rates, radical surgical resection is the best approach to achieve complete tumor removal and, although rarely, offer a chance for long-term survival in patients with PHA.

\section{Abbreviations}

DFS: Disease-free survival; LT: Liver transplantation; OS: Overall survival; PHA: Primary hepatic angiosarcoma; TACE: Transcatheter arterial chemoembolization;

TAE: Transcatheter arterial embolization; TARE: Transarterial radioembolization

Acknowledgements

Not applicable.

\section{Funding}

Not applicable.

\section{Availability of data and materials}

The datasets used and analyzed during the current study are available from the corresponding author on reasonable request.

\section{Authors' contributions}

All authors read and approved the final manuscript. VT: obtained and analyzed data, preparation of manuscript. SH: designed and revised study. $\mathrm{TH}$ : acquisition of data. JM: interpretation of data and drafted paper. $\mathrm{MH}$ : acquisition of data. BS: acquisition of data and histopathologic work-up. $\mathrm{HL}$ : designed and revised study.

\section{Ethics approval and consent to participate}

Not applicable.

\section{Consent for publication}

Not applicable.

\section{Competing interests}

The authors declare that they have no competing interests.

\section{Publisher's Note}

Springer Nature remains neutral with regard to jurisdictional claims in published maps and institutional affiliations.

\section{Author details}

'Department of General, Visceral and Transplantation Surgery, University Hospital of Mainz, Langenbeckstrasse 1, 55131 Mainz, Germany. ${ }^{2}$ Institute of Pathology, University Hospital of Mainz, Mainz, Germany.

Received: 25 October 2018 Accepted: 20 December 2018 Published online: 10 January 2019

\section{References}

1. Molina $\mathrm{E}$, Hernandez A. Clinical manifestations of primary hepatic angiosarcoma. Dig Dis Sci. 2003;48:677-82.

2. Elliott P, Kleinschmidt I. Angiosarcoma of the liver in Great Britain in proximity to vinyl chloride sites. Occup Environ Med. 1997;54:14-8.

3. Salgado M, Sans M, Forns X, Bruguera M, Castells A, Navasa M, Rodés J. Hepatic angiosarcoma: a report of a case associated with treatment with arsenic salts and a review of the literature. Gastroenterol Hepatol. 1995;18: 132-5.

4. Kojiro M, Nakashima T, Ito Y, Ikezaki H. Pathomorphological study on thorotrast-induced hepatic malignancies. Strahlentherapie Sonderb. 1985;80: 119-22.

5. Falk $H$, Thomas LB, Popper $H$, Ishak KG. Hepatic angiosarcoma associated with androgenic-anabolic steroids. Lancet. 1979;2:1120-3.

6. Zheng YW, Zhang XW, Zhang JL, Hui ZZ, Du WJ, Li RM, Ren XB. Primary hepatic angiosarcoma and potential treatment options. J Gastroenterol Hepatol. 2014;29:906-11.

7. Duan XF, Li Q. Primary hepatic angiosarcoma: a retrospective analysis of 6 cases. J Dig Dis. 2012;13:381-5. 
8. Asmane I, Litique V, Heymann S, Marcellin L, Métivier AC, Duclos B, Bergerat JP, Kurtz JE. Adriamycin, cisplatin, ifosfamide and paclitaxel combination as front-line chemotherapy for locally advanced and metastatic angiosarcoma. Analysis of three case reports and review of the literature. Anticancer Res. 2008;28:3041-5.

9. Park YS, Kim JH, Kim KW, Lee IS, Yoon HK, Ko GY, Sung KB. Primary hepatic angiosarcoma: imaging findings and palliative treatment with transcatheter arterial chemoembolization or embolization. Clin Radiol. 2009;64:779-85.

10. Miller MD, Sze DY, Padia SA, Lewandowski RJ, Salem R, Mpofu P, Haste PM, Johnson MS. Response and overall survival for Yttrium-90 Radioembolization of hepatic sarcoma: a multicenter retrospective study. J Vasc Interv Radiol. 2018;29:867-73.

11. Dindo D, Demartines N, Clavien PA. Classification of surgical complications: a new proposal with evaluation in a cohort of 6336 patients and results of a survey. Ann Surg. 2004;240:205-13.

12. Zhou YM, Li B, Yin ZM, Xu F, Wang B, Xu W, Liu P, Yang JM. Results of hepatic resection for primary hepatic angiosarcoma in adults. Med Sci Monit. 2010;16:Cr61-6.

13. Kim HR, Rha SY, Cheon SH, Roh JK, Park YN, Yoo NC. Clinical features and treatment outcomes of advanced stage primary hepatic angiosarcoma. Ann Oncol. 2009;20:780-7.

14. Huang IH, Wu YY, Huang TC, Chang WK, Chen JH. Statistics and outlook of primary hepatic angiosarcoma based on clinical stage. Oncol Lett. 2016;11: 3218-22.

15. Matthaei $H$, Krieg A, Schmelzle M, Boelke E, Poremba C, Rogiers X, Knoefel WT, Peiper M. Long-term survival after surgery for primary hepatic sarcoma in adults. Arch Surg. 2009;144:339-44.

16. Husted TL, Neff G, Thomas MJ, Gross TG, Woodle ES, Buell JF. Liver transplantation for primary or metastatic sarcoma to the liver. Am J Transplant. 2006;6:392-7.

17. Orlando G, Adam R, Mirza D, Soderdahl G, Porte RJ, Paul A, Burroughs AK, Seiler CA, Colledan M, Graziadei I, Garcia Valdecasas JC, Pruvot FR, Karam V. Hepatic hemangiosarcoma an absolute contraindication to liver transplantation--the European Liver Transplant Registry experience. Transplantation. 2013:95:872-7.

18. Bonaccorsi-Riani E, Lerut JP. Liver transplantation and vascular tumors. Transpl Int. 2010;23:686-91.

19. Tran Minh M, Mazzola A, Perdigao F, Charlotte F, Rousseau G, Conti F. Primary hepatic angiosarcoma and liver transplantation: radiological, surgical, histological findings and clinical outcome. Clin Res Hepatol Gastroenterol. 2018:42:17-23.

20. Fletcher CDM. The evolving classification of soft tissue tumours-an update based on the new 2013 WHO classification. Histopathology. 2014;64:2-11.

21. Bruegel M, Muenzel D, Waldt S, Specht K, Rummeny EJ. Hepatic angiosarcoma: cross-sectional imaging findings in seven patients with emphasis on dynamic contrast-enhanced and diffusion-weighted MRI. Abdom Imaging. 2013;38:745-54.

22. Penel N, Bui BN, Bay JO, Cupissol D, Ray-Coquard I, Piperno-Neumann S, Kerbrat P, Fournier C, Taieb S, Jimenez M, Isambert N, Peyrade F, Chevreau C, Bompas E, Brain EG, Blay JY. Phase II trial of weekly paclitaxel for unresectable angiosarcoma: the ANGIOTAX study. J Clin Oncol. 2008;26: 5269-74.

23. Weitz J, Klimstra DS, Cymes K, Jarnagin WR, D'Angelica M, La Quaglia MP, Fong Y, Brennan MF, Blumgart LH, Dematteo RP. Management of primary liver sarcomas. Cancer. 2007;109:1391-6.

24. Huang NC, Wann SR, Chang HT, Lin SL, Wang JS, Guo HR. Arsenic, vinyl chloride, viral hepatitis, and hepatic angiosarcoma: a hospital-based study and review of literature in Taiwan. BMC Gastroenterol. 2011;11:142.

25. Chi TY, Yang ZY, Xue HD, Lü K, Feng RE, Xu HF, Yang XB, Sang XT, Lu X, Mao YL, Zhong SX, Huang JF. Diagnosis and treatment of primary hepatic angiosarcoma: a report of 7 cases with a literature review. Zhonghua Yi Xue Za Zhi. 2011:91:1694-7.

26. Hur CJ, Min BR, Lee YJ, Jang BK, Hwang JS, Kim ES, Park KS, Cho KB, Kang YN, Chung WJ. Clinical courses of primary hepatic angiosarcoma: retrospective analysis of eight cases. Korean J Gastroenterol. 2015;65:229-35.

27. Zhu YP, Chen YM, Matro E, Chen RB, Jiang ZN, Mou YP, Hu HJ, Huang CJ, Wang GY. Primary hepatic angiosarcoma: a report of two cases and literature review. World J Gastroenterol. 2015;21:6088-96.

\section{Ready to submit your research? Choose BMC and benefit from:}

- fast, convenient online submission

- thorough peer review by experienced researchers in your field

- rapid publication on acceptance

- support for research data, including large and complex data types

- gold Open Access which fosters wider collaboration and increased citations

- maximum visibility for your research: over $100 \mathrm{M}$ website views per year

At BMC, research is always in progress.

Learn more biomedcentral.com/submissions 